\title{
Työttömät koulunpenkille vai koulunpenkiltä työttömäksi?
}

Tämän lehden edellinen numero oli omistettu aikuiskoulutukselle ja työllisyydelle -ajankohtainen teema ja tärkeä keskustelunaihe varsinkin tämän päivän Suomessa. Onko koulutus siis ratkaisu työttömyyteen? Miten koulutus työttömyyteen liittyy? Yleisin väite lienee, että koulutusta hankkimalla voi suojautua työttömyydeltä. Tämä väite on helppo kumota pelkästään tutkimalla akateemista työttömyyttä kuvaavia tilastoja. Toinen yhtä yleinen väite on, että työttömyyttä kannattaa katkaista koulutuksella.

Työttömyyden ja koulutuksen välisiä yhteyksiä voi tarkastella monilla eri tavoilla. Aluksi on syytä todeta, että päätoimisesti opiskelevat eivät työhallinnon nykymäärittelyin yleensä voi olla samaan aikaan työttömiä eli koulutus ainakin tilapäisesti "kaunistaa" työttömyyslukuja, tahdoimmepa tai emme. Kyseessä on koulutuksen varastointifunktio, joka toimii täysin riippumatta koulutuksen sopivuudesta tai vaikuttavuudesta. Sama funktio on myös perus- ja nuorisoasteen koulutuksella: lapset ja nuoret saadaan aikuisten mielestä järkevän toiminnan piiriin pois pahanteosta.

Jos kuitenkin haluaa analysoida koulutuksen varastointifunktiota hieman pitemmälle, voi siinä nähdä työttömien suhteen kaksi keskeistä piirrettä. Ensinnäkin kyse on pitkälti myös määrittelyistä ja sopimuksista: kuka tulkitaan työttömäksi ja kuka ei. Voidaan myös tulkita työtön (siis työtä vailla oleva) työttömäksi niin kauan, kuin hän on työtä vailla ja sitä haluaa riippumatta siitä, mitä hän kulloinkin tekee. Toinen seikka on sisällöllisempi, ja liittyy työttömyyden katkaisuun. Paitsi tilastollista ja näennäistä merkitystä työttömyyden katkaisulla voi olla henkilölle myös sisällöllistä merkitystä elämäntilanteen kannalta. Olla työtön on jotain kielteistä, olla jotain muuta, vaikkapa opiskelija, on yhteiskunnan ja lähiyhteisön silmissä ja siten myös omissa silmissä jotain parempaa, myönteisempää. Tietysti tästä näkökulmasta mikä tahansa aktiivinen ja hyväksyttävä toiminta palvelee yhtä hyvin tätä tarkoitusta. Voi myös väittää, että teoriassa koulutus toteuttaa varastointi- ja työttömyyden katkaisufunktiota aina riippumatta sen sisällöstä.

\section{Ihminen pyrkii luonnostaan eteen päin}

Työttömien kouluttamisella voi kuitenkin nähdä merkitystä myös työmarkkinoiden kannalta. Aikanaan 70-luvulla korostettiin työvoimapoliittisten toimien tuotannon ja talouden kasvua tukevaa merkitystä: $\mathrm{mm}$. silloisen työllisyyskoulutuksen tehtävänä oli varmistaa oikeanlaisen työvoiman saatavuus kasvavan ja monipuolistuvan tuotantoelämän tarpeisiin kouluttamalla työvoimareserviä. Työllisyyskoulutus palvelikin melko hyvin tätä tarkoitusta. Oli työpaikkoja, joihin kouluttaa ja joiden ammattitaitovaatimukset olivat suhteellisen selkeitä ja yksinkertaisia. Ammatitkin olivat tai ne nähtiin siihen aikaan vielä selvärajaisina, tosin usein myös samalla kapea-alaisina.

Tilanne on ratkaisevasti muuttunut, työpaikkoja joihin kouluttaa ei enää suuremmassa in ole. Ammattien rajat ovat tulleet häilyviksi, osaamisvaatimukset työmarkkinoilla ovat monitasoisia, moniulotteisia ja epämääräisiä. Siitä huolimatta "sopivan" työvoiman saatavuuden turvaamista korostetaan työvoimapolitiikassa edelleen toisen tärkeän painoalueen, alkavan yritystoiminnan tukemisen ohella (mm. työministeriön TTS 1997-2000). 
Mihin työttömiä sitten tänä päivänä koulutetaan? On selvää, että työmarkkinat eivät nykyisellään enää vedä kuten ennen, sen osoittavat korkealla pysyvät työttömyysluvut. Työttömiä ei voida enää kouluttaa työmarkkinoiden kasvaviin tarpeisiin, koska niitä ei ole. Voidaan myös väittāä, että työttömiä kouluttamalla ja heidän työmarkkinavalmiuksiaan parantamalla vain siirretään ongelmaa, koulutetun asema työvoimajonossa voi parantua, mutta samalla jonkun toisen todennäköisesti heikentyy.

Oman työvoimakoulutusta koskevan tutkimukseni tulosten perusteella olen kuitenkin tullut vakuuttuneeksi, että työttömällä, joka vapaaehtoisesti koulutukseen hakeutuu, on itse selvä koulutustarve ja usko koulutuksen merkitykseen. Hän tietää, että koulutus ei takaa työllistymistä, mutta hän haluaa silti tulla kurssille. Miksi? Ehkä eräs syy on, että ihminen on luonnostaan eteenpäin pyrkivä ja kehittymistä tavoitteleva. Hän kärsii jos hän kokee jossain suhteessa, esimerkiksi ammatillisesti tai sosiaalisesti, taantuvansa. Yli 80 prosenttia tutkimukseni kohderyhmästä, työvoimakoulutukseen osallistuneista, arveli halun kehittää itseään vaikuttaneen ainakin jossain määrin koulutukseen hakeutumiseensa. Työttömyyden ja toimettomuuden tilalle halutaan toimintaa, joka todistaa ennen kaikkea henkilölle itselleen hänen merkitystään, ihmisarvoaan ja kehittymiskykyään. Tärkeimmät osallistujien kokemat työvoimakoulutuksenvaikuttavuusalueet olivatkin tutkimuksessani itsetunto ja ammattitaito (60-70 prosenttia arvioi koulutuksen omalta osaltaan vaikuttaneen niihin myönteisesti). Työttömien koulutusta voidaan siis perustella myös heidän omilla tarpeillaan ja pyrkimyksillään.

\section{Työvoiman tarve on eri osia kuin avointen työpaikkojen määrä}

Toinen perustelu liittyy työmarkkinoihin ja niiden muutoksiin. Työvoiman todellinen tarve on eri asia kuin työpaikkojen, avointen tai täytettyjen, määrä, joka riippuu ehkä lopulta enemmän työvoiman palkkauskustannuksista kuin työvoiman tarpeesta. Ajatellaanpa vaikka tällä hetkellä palkattomana kotityönä ja omaishoitona tehdyn työn määrää. Miten paljon Suomen työmarkkinat todella voisivat työllistää, on ratkaisematon kysymys. Toinen seikka, johon Suikkanenkin viittaa, on työsuhteiden muuttuminen yhä kauemmas normaalityösuhteesta, ja toisaalta palkatun työn väheneminen ja korvautuminen yhä enemmän yrittäjien, ammatinharjoittajien, free lancereiden ja keikkatyöntekijöiden työllä. Tällaisille työmarkkinoille sijoittumista koulutus voi edistää mm. auttamalla ihmisiä löytämään omia vahvuusalueitaan ja mahdollisuuksiaan ja vahvistamalla heidän uskoaan omaan osaamiseensa. Manninen viittaa myös tarpeeseen tuottaa uutta osaamista ja innovaatioita koulutuksen avulla.

\section{Milloin koulutus on vaikuttavaa?}

Aktiivisen työvoimapolitiikan keinoista työvoimakoulutus on Suomessa edelleen keskeisimpiä tukityöllistämisen ohella. Työvoimakoulutuksen vaikuttavuutta on julkisessa keskustelussa kyseenalaistettu ja epäilty koulutuksen olevan lähinnä tilastojen kaunistelua, ts. palvelevan pääasiassa varastointifunktiota. Jos vaikuttavuus tulkitaan vain työllistäväksi vaikutukseksi, toisin sanoen tavoitteena pidetään vain nopeaa työllistymistä koulutuksen avulla, työvoimakoulutus ei kovin vaikuttavaa olekaan. Kuten Manninen toteaa, työllistymiskriteerin käytössä vaikuttavuuden ainoana arviointikriteerinä on kuitenkin monia ongelmia. Niistä vähäisin ei liene se, että koulutuksen työllistymistä ylipäänsä edistäviä mekanismeja ja niihin liittyviä aikaviiveitä tunnetaan perin huonosti.

Koulutuksen vaikuttavuutta voi kuitenkin arvioida myös muusta kuin lyhyen tähtäimen työllistymistavoitteen näkökulmasta kieltämättä kuitenkaan sen tärkeyttä. Jos tunnustetaan se tosiasia, että työmarkkinat ovat muuttuneet eikä normaalipalkkatyösuhde-malli enää toimi, voidaan vaikuttavuutta arvioida tarkastelemalla koulutettujen työmarkkinapolkuja pitemmällä aikavälillä ja vertaamalla niitä ei-koulutettujen polkuihin samana aikana. Voidaan arvioida, väheneekö työttömyysjaksojen osuus ja kasvaako työssäolojaksojen osuus, tai tapahtuuko muutoksia ammatillisessa joustossa tai liikkuvuudessa tietyn ajan kuluessa. Voidaan myös kysyä koulutukseen osallistuneilta itseltään, millaisia vaikutuksia he ovat eri elämänalueilla havainneet ja kokeneet. Monesta näkökulmasta ja monilla eri kriteereillä arvioituna 
koulutuksen vaikuttavuudesta on mahdollista muodostaa monipuolisempi ja ehkä myös luotettavampi kuva kuin yksinomaan työllistymiskriteeriä käyttämällä.

Omien tutkimustulosteni perusteella olen tullut sensuuntaisiin johtopäätöksiin, että työvoimakoulutuksella on vain heikkoja yhteyksiä koulutettujen työllistymiseen ansiotyöhön, mutta selvempiä yhteyksiä työllistymiseen oman yritystoiminnan kautta. Työttömyys on vähentynyt koulutettujen työmarkkinapoluilla enemmän kuin ei-koulutettujen myös siksi, että opiskeluun käytetyn ajan osuus on edellisillä suurempi myös työvoimakoulutuksen jälkeen. Osallistujien itsensä kokemat myönteiset vaikutukset kohdistuvat taas ennen kaikkea itsetuntoon, elämäntilanteeseen yleensä ja ammattitaitoon.

\section{Työvoimapoliittisella koulutuksella on tärkeä taso-arvofunktio}

Vaikka työvoimakoulutuksesta yhtenä yksikäsitteisenä ilmiönä ei pitäisi enää puhua, koska koulutus on monipuolistunut ja pitkälle eriytynyt, voi sen järkevyydestä yleensä kuitenkin tehdä joitakin johtopäätöksiä. Kuten kaikessa koulutuksessa, myös työvoimakoulutuksessa on laatuongelmia, varsinkin nyt kun tarjonta on nopeasti kasvanut ja samaan aikaan hintoja painetaan alas. Sekä työvoima- että koulutuspoliittisesti se mielestäni kuitenkin puoltaa paikkaansa yhtenä aikuiskoulutuksen muotona. Työttömät(kin) tarvitsevat koulutusta, ja jos yhteiskunta voi sitä heille ilmaiseksi tarjota, toteutuu myös koulutuksen tasa-arvofunktio ainakin osittain. Koulutuksen tulee kuitenkin sekä vastata koulutettavien yksilöllisiä tarpeita että ohjata jotain kautta heidän työmarkkinapolkujaan kauemmas työttömyydestä ja syrjäytymisuhasta. Työllistämisautomaatti se sen sijaan ei voi olla. 